\title{
デッキプレート床の而火試験
}

正会員川越邦雄* 同 斎 藤 光** 同 三 渡 善男***

\section{1. 多目的重油耐火試験炉}

昭和 34 年、長さ $4 \mathrm{~m}$, $2 \mathrm{~m}$, 深 $3 \mathrm{~m}$ の重油炉を築 造。仕切を設けることにより、 $4 \times 2 \mathrm{~m}$ の床・梁、 $3 \mathrm{~m}$ の柱、 $3 \times 3 \mathrm{~m}$ の骨組の 耐火験試が可能。載荷 100 ton まで。

\section{2. デッキプレート床試験体、試験方法}

V型デッキプレート、梁間 $2.2 \mathrm{~m}$ ，巾 $1.86 \mathrm{~m}, 16$ 面。
仕上は第 1 表の通り。炉中央に梁を設け、コンクリート シリンダーで載荷し、2 面ずつ加熱。

W型デッキプレート、梁間 $4.5 \mathrm{~m}$, 巾 $1.8 \mathrm{~m}, 19$ 面。 仕上は第 2 表の通り。コンクリートシリンダーで載荷し 1 面ずつ加熱。

\section{3. 試験結果}

要点を第 1 表、第 2 表に示す。

第 1 表 V デッキプレート試験結果

\begin{tabular}{|c|c|c|c|c|c|c|c|c|}
\hline No. & 仕 上 材 料 & $\begin{array}{c}\text { 荷 重 } \\
\left(\mathbf{k g} / \mathbf{m}^{2}\right)\end{array}$ & $\begin{array}{l}\text { 降伏時間 } \\
\text { (分) }\end{array}$ & $\mid \begin{array}{l}\text { 降伏開始㭙 } \\
\text { O推 }(\mathrm{cm})\end{array}$ & $\begin{array}{l}\text { 加驇時間 } \\
\text { (分) }\end{array}$ & $\begin{array}{c}\text { 最大挤 } \\
(\mathrm{cm})\end{array}$ & $\begin{array}{l}\text { 鉄板最高 } \\
\text { 温度 }\left({ }^{\circ} \mathrm{C}\right)\end{array}$ & 備 \\
\hline 7 & & 63 & 10 & 1.0 & 35 & 18.6 & 855 & \\
\hline 8 & デッキプレートのみ & 0 & $\begin{array}{l}35 \text { 分で } \\
\text { 降伏过ず }\end{array}$ & - & 35 & - & 795 & \\
\hline $\begin{array}{l}1 \\
2 \\
3 \\
4\end{array}$ & $\begin{array}{ll}\text { 上面 } & \text { 軽量コンクリート打 } \\
\text { (4 cm 厚) } \\
\text { 下面 被覆なし }\end{array}$ & $\begin{array}{l}50 \\
50 \\
75 \\
50 \\
\end{array}$ & $\begin{array}{l}- \\
15 \\
20\end{array}$ & $\begin{array}{l}\overline{-} \\
\overline{1.0} \\
1.0\end{array}$ & $\begin{array}{l}45 \\
45 \\
45 \\
45 \\
\end{array}$ & $\begin{array}{l}\overline{-} \\
\overline{18.1} \\
13.3\end{array}$ & $\begin{array}{l}800 \\
620 \\
800 \\
820 \\
\end{array}$ & \\
\hline $\begin{array}{l}15 \\
16\end{array}$ & 上面 同一上ボンド & $\begin{array}{r}75 \\
100\end{array}$ & $\begin{array}{l}15 \\
15\end{array}$ & $\begin{array}{l}1.5 \\
1.5\end{array}$ & $\begin{array}{l}60 \\
60\end{array}$ & $\begin{array}{l}17.0 \\
12.5\end{array}$ & $\begin{array}{l}860 \\
740\end{array}$ & \\
\hline $\begin{array}{l}11 \\
12\end{array}$ & 上面 同 卡ズードプラスター & $\begin{array}{r}75 \\
100 \\
\end{array}$ & $\begin{array}{l}20 \\
20\end{array}$ & $\begin{array}{l}0.3 \\
1.1\end{array}$ & $\begin{array}{l}60 \\
60\end{array}$ & $\begin{array}{l}17.4 \\
20.5\end{array}$ & $\begin{array}{l}840 \\
900\end{array}$ & 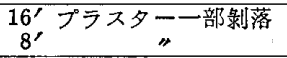 \\
\hline $\begin{array}{c}9 \\
10\end{array}$ & 上面 同 上゚ーラィトボート & $\begin{array}{r}75 \\
100\end{array}$ & $\begin{array}{l}45 \\
40\end{array}$ & $\begin{array}{l}0.9 \\
1.2\end{array}$ & $\begin{array}{l}60 \\
60\end{array}$ & $\begin{array}{l}4.3 \\
9.6\end{array}$ & $\begin{array}{l}560 \\
950\end{array}$ & $\begin{array}{l}10^{\prime} \\
12^{\prime}\end{array}$ \\
\hline 13 & 上面 同卡 & 75 & $\begin{array}{l}2 \text { 級で } \\
\text { 降伏さずす }\end{array}$ & 一 & 120 & 2.0 & 470 & 15'モルタル一部剩落 \\
\hline 14 & 上面 同フ战 & 100 & $\Rightarrow$ & - & 120 & 2.5 & 512 & モルタル剶落なし \\
\hline 5 & 上面 同に上下ムレックス $(3 \mathrm{~cm})$ & 75 & $\begin{array}{l}1 \text { 級で } \\
\text { 降伏せず }\end{array}$ & - & 180 & 1.2 & 220 & トムレックス剩落なし \\
\hline 6 & 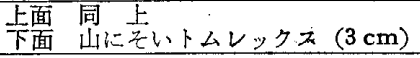 & 75 & $"$ & - & 180 & 1.9 & 425 & " \\
\hline
\end{tabular}

第 2 表 Wデッキプレート試験 結果

\begin{tabular}{|c|c|c|c|c|c|c|c|c|c|}
\hline No. & & 仕 上 材 料 & $\begin{array}{l}\text { 荷 } \\
\left(\mathrm{kg} / \mathrm{m}^{2}\right) \\
\end{array}$ & $\begin{array}{l}\text { 降伏時間 } \\
\text { (分) }\end{array}$ & $\left|\begin{array}{|l}\mid \text { 降伏開始時 } \\
\text { 接 }(\mathrm{cm})\end{array}\right|$ & $\begin{array}{l}\text { 加熱時間 } \\
\text { (分) }\end{array}$ & $\begin{array}{c}\text { 最大暁 } \\
(\mathrm{cm})\end{array}$ & $\begin{array}{l}\text { 鉄板最高 } * \mid \\
\text { 温度 }\left({ }^{\circ} \mathrm{C}\right)\end{array}$ & 備 \\
\hline WD-3 & 卡面 & $\begin{array}{l}\text { リブラスコンクリート }(4 \mathrm{~cm}) \\
\text { な }\end{array}$ & $\begin{array}{l}200 \\
100 \\
\end{array}$ & 10 & 5.5 & 30 & 23.3 & $\begin{array}{c}850 \\
910\end{array}$ & \\
\hline WD-1 & 上面 & $\begin{array}{l}\text { ヨンクリート打 } \\
\text { な }\end{array}$ & 150 & 20 & 7.5 & 60 & 18.3 & $\begin{array}{c}755 \\
605 \\
\end{array}$ & \\
\hline WD-2 & 上面 & $\begin{array}{l}\text { 軽量コンクリート打 } \\
\text { な }\end{array}$ & $\begin{array}{l}200 \\
100\end{array}$ & 15 & 9.0 & 40 & 31.5 & $\begin{array}{r}810 \\
835\end{array}$ & \\
\hline$W-10$ & 上面 & $\begin{array}{l}\text { リブラスコンクリート (4cm) } \\
\text { 石綿十スーパーホーン }\end{array}$ & 300 & 30 & 0.7 & 40 & 7.7 & $\begin{array}{c}395 \\
390 \\
\end{array}$ & $\begin{array}{l}27^{\prime} \sim 30^{\prime} \text { 端部のスーパーホーン } \\
\text { 落下 }\end{array}$ \\
\hline WD-7 & 上面 & 同りジールプラスター & $\begin{array}{l}200 \\
100\end{array}$ & 65 & 1.5 & 80 & 30.1 & $\begin{array}{c}910 \\
585\end{array}$ & 65'ドリゾール全面落下 \\
\hline WD-5 & \multirow{4}{*}{$\begin{array}{l}\text { 上面 } \\
\text { 下面 }\end{array}$} & \multirow{4}{*}{$\begin{array}{l}\text { 同 } \\
\text { リブラスコンクリート }(4 \mathrm{~cm}) \\
\text { リプラス、石高プラスター- }\end{array}$} & $\begin{array}{l}200 \\
100 \\
\end{array}$ & 95 & 8.2 & 120 & 21.8 & $\begin{array}{c}765 \\
745 \\
\end{array}$ & $\begin{array}{l}4^{\prime} \sim 30^{\prime} フ^{\prime} \text { ラスター落下 } \\
95^{\prime} \text { 頃全面落下 }\end{array}$ \\
\hline$W-4_{A}$ & & & 300 & 70 & 4.0 & 90 & 9.6 & $\begin{array}{c}540 \\
495 \\
\end{array}$ & $\begin{array}{l}4^{\prime} \text { 上りプラスター落下 } \\
6^{\prime} \text { で全面落下 }\end{array}$ \\
\hline$W-4 B$ & & & 300 & 90 & 4.8 & 100 & 18.1 & $\begin{array}{c}580 \\
585 \\
\end{array}$ & $\begin{array}{l}4^{\prime} \text { よりプラスター落下 } \\
5^{\prime} \sim 6^{\prime} \text { で夫半落下 }\end{array}$ \\
\hline$w-4 c$ & & & 300 & 75 & 5.0 & 90 & 12.3 & $\begin{array}{c}595 \\
570 \\
\end{array}$ & $\begin{array}{l}3^{\prime} \text { よりプラスター落下 } \\
5^{\prime} \sim 6^{\prime} \text { 全面落下 }\end{array}$ \\
\hline WD-4 & \multirow{4}{*}{$\begin{array}{l}\text { 上面 } \\
\text { 下面 }\end{array}$} & \multirow{4}{*}{$\begin{array}{l}\text { 同上 } \\
\text { リブラス、パーライトモルタル }\end{array}$} & $\begin{array}{l}200 \\
100\end{array}$ & 165 & 4.5 & 180 & 7.0 & $\begin{array}{c}570 \\
430 \\
\end{array}$ & パーライトモルタルごく一部落下 \\
\hline $\mathrm{W}-2_{\mathrm{A}}$ & & & 300 & 115 & 4.0 & 135 & 14.2 & $\begin{array}{c}510 \\
510 \\
\end{array}$ & $20^{\prime}$ 中央部大きく落下 \\
\hline$W-2_{B}$ & & & 300 & $\begin{array}{l}2 \text { 級 で } \\
\text { 降伏せず }\end{array}$ & - & 120 & 2.5 & $\begin{array}{c}365 \\
365 \\
\end{array}$ & パーライトモルタル落下なし \\
\hline$W-2 c$ & & & 300 & $"$ & - & 120 & 3.5 & $\begin{array}{c}485 \\
440 \\
\end{array}$ & パーライトモルタルごく一部落下 \\
\hline $\mathbf{W}-9$ & $\begin{array}{l}\text { 上面 } \\
\text { 下面 }\end{array}$ & 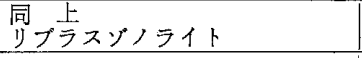 & 300 & $"$ & - & 120 & 4.3 & $\begin{array}{c}450 \\
380 \\
\end{array}$ & ゾノライト落下なし. \\
\hline WD-6 & \multirow{4}{*}{$\begin{array}{l}\text { 上面 } \\
\text { 下面 }\end{array}$} & \multirow{4}{*}{$\begin{array}{l}\text { 同上 } \\
\text { リプラス、トムレックス }\end{array}$} & $\begin{array}{l}200 \\
100\end{array}$ & 85 & 1.5 & 180 & 15.2 & $\begin{array}{c}875 \\
705 \\
\end{array}$ & トムレックス大きく落下 \\
\hline$W-5_{A}$ & & & 300 & $\begin{array}{c}2 \text { 級 で } \\
\text { 降伏せず }\end{array}$ & - & 120 & 1.6 & $\begin{array}{c}260 \\
250 \\
\end{array}$ & トムレックス一部落下 \\
\hline$W-5 B$ & & & 300 & $"$ & - & 120 & 2.7 & $\begin{array}{c}360 \\
340 \\
\end{array}$ & トムレックス一部落下 \\
\hline$W-5 c$ & & & 300 & " & - & 120 & 1.7 & $\begin{array}{c}280 \\
260\end{array}$ & トムレカタス落下なし \\
\hline W-8 & $\begin{array}{l}\text { 上面 } \\
\text { 下面 }\end{array}$ & $\begin{array}{l}\text { 同上 } \\
\text { リプラスリンペット } \\
\text { +石綿板 (孔明) }\end{array}$ & 300 & $"$ & - & 120 & 1.9 & $\begin{array}{r}170 \\
135\end{array}$ & リンペット一部落下 \\
\hline
\end{tabular}

* 鉄板山及び谷部の平均温度 